\title{
Safety Profile of Mutant EGFR-Tyrosine Kinase Inhibitors in Advanced Non-Small Cell Lung Cancer: Meta-Analysis and Literature to Review
}

abubakar Tauseef ( $\square$ abubakartauseef@creighton.edu )

Creighton University https://orcid.org/0000-0002-4317-1868

\section{Maryam Zafar}

Dow University of Health Sciences

Peter Silberstein

Creighton University School of Medicine

Joseph Nahas

Creighton University School of Medicine

Thomas Frederickson

Creighton University

\section{Anum Abbas}

University of Nebraska Medical Center College of Medicine

Yaman Alali

Creighton University

\section{Sean Hansen}

Creighton University

omar Abughanimeh

University of Nebraska Medical Center College of Medicine

Mohsin Mirza

Creighton University

\section{Research Article}

Keywords: Safety, mutant EGFR-TK inhibitors, advanced, non-small lung cancer, literature, meta-analysis

Posted Date: November 22nd, 2021

DOI: https://doi.org/10.21203/rs.3.rs-1055015/v1

License: (c) (i) This work is licensed under a Creative Commons Attribution 4.0 International License. Read Full License 


\section{Abstract}

Despite the use of platinum-based chemotherapy, lung cancer continues to be the leading cause of cancer related death in the world. To overcome the rate of lung cancer related death, scientists discovered advanced therapies including mutant Epidermal Growth Factor Receptor-tyrosine kinase (EGFR-TK) inhibitors. Included in this study are nine phase 3 randomized controlled trials designed to study the safety profile of mutant EGFR-TK inhibitors in patients with advanced non-small cell lung cancer. The study showed that mutant EGFR-TK inhibitors have an incidence of adverse effects that is far less than platinum-based chemotherapy. Adverse effects reported were tolerable and easily manageable by slowing the infusion rate, decreasing the dosage, and skipping a dosage in symptomatic patients.

\section{Introduction}

Lung cancer has been the leading cause of cancer related mortality for decades. It is also predicted to remain as the leading cause of cancer related mortality through 2030. [1]. Platinum-based chemotherapy including carboplatin and paclitaxel, introduced 3 decades ago, has revolutionized the management of advanced non-small cell lung carcinoma. A more recent advancement has been mutant EGFR tyrosine kinase inhibitors [1]. Epidermal growth factor receptor is a transmembrane protein that functions by transducing essential growth factor signaling from the extracellular milieu to the cell. As $60 \%$ of the advanced non-small cell carcinoma expresses this receptor, blocking the mutant EGFR receptor was a groundbreaking development in the management of advanced non-small cell lung carcinoma [2]. Development of mutant EGFR tyrosine kinase inhibitors has revolutionized the management of advanced non-small cell lung carcinoma. This study was conducted to determine the safety profile of mutant EGFR tyrosine kinase inhibitors in the management of advanced non-small cell lung carcinoma.

\section{Method And Methodology}

This meta-analysis was conducted according to Cochrane Collaboration guidelines and reported as per Preferred Reporting Items for Systematic Reviews and Meta-Analyses (PRISMA) guidelines. The findings are summarized in the PRISMA flow chart. Two authors (MZ and MM) performed a systematic literature search using databases such as MEDLINE (via PubMed), Embase, and Cochrane library using the medical search terms and their respective entry words with the following search strategy: "Safety, mutant EGFR tyrosine kinase inhibitors, Advanced, Non-small cell, Lung cancer, Adverse effect and Literature". Additionally, unpublished trials were identified from the clinicaltrials.gov website and references of all pertinent articles were also scrutinized to ensure the inclusion of all relevant studies. The search was completed on June $1^{\text {st }}, 2021$ and we only included studies available in English. Two authors (MM and MZ) independently screened the search results in a two-step process based on predetermined inclusion/exclusion criteria. First 890 articles were evaluated for relevance on title and abstract level, followed by full-text screening of the final list of 140 articles. Any dis-agreements were resolved by discussion or third-party review and a total of nine articles were included in the study. The following eligibility criteria were used: original articles reporting adverse effects of mutant EGFR tyrosine kinase inhibitors in patients with advanced non-small cell lung carcinoma as compared to control groups receiving platinum-based chemotherapy. All articles with subjective data on the adverse effects of mutant EGFR tyrosine kinase inhibitors in patients with advanced non-small cell lung carcinoma as compared to control groups receiving platinum-based chemotherapy were included in the analysis. Only nine articles qualified the aforementioned selection criteria for eligibility. All qualifying studies were nationwide inpatient or pooled clinical trials data. The reasons for exclusion of other 71 articles were: irrelevant ( $\mathrm{n}=31$ ), duplicate $(n=13)$, reviews $(n=14)$ and poor data reporting $(n=12)$. Out of the nine included studies, nine studies showed correlation of adverse effects including rash, diarrhea, nausea, and fatigue. Seven studies showed correlation of adverse effects including neutropenia, anorexia, and vomiting. Six studies showed correlation of anemia, cough, and stomatitis. Five studies showed correlation of elevated aspartate aminotransferase, alanine aminotransferase and leucopenia. Four studies showed correlation of fever in between mutant EGFR tyrosine kinase inhibitors and platinumbased chemotherapy.

The primary endpoint was adverse effects including rash, diarrhea, elevated alanine aminotransferase, elevated aspartate aminotransferase, stomatitis, nausea, leucopenia, fatigue, neutropenia, anorexia, anemia, cough, vomiting and fever respectively. Data on baseline characteristics and clinical outcomes were then extracted and summary tables were created. Summary estimates of the clinical endpoints were then calculated with risk ratio (RR) and 95\% confidence intervals using the random-effects model. Heterogeneity between studies was examined with the Cochran's Q based I2 statistic which can be defined as low (25\% to $50 \%)$, moderate ( $50 \%$ to $75 \%)$, or high ( $>75 \%)$. Statistical analysis was performed using Comprehensive Meta-analysis software (CMA version 3.0, Biostat Inc).

\section{Results}

A total of 9 studies including 3415 patients (1775 in EGFR inhibitor-treatment group while 1640 patients in platinum-based chemotherapy-control group were included in the study. All nine studies included were phase III randomized control clinical trials conducted to compare the safety profile of mutant EGFR tyrosine kinase inhibitors in patients with advanced non-small cell lung carcinoma. Mean age was 61 years in both treatment and control groups. Further details on study and participant characteristics and safety profile including adverse effects are summarized in Tables $1,2 \mathrm{~A}$ and 2B respectively. No evidence of publication bias was found (Prisma flow chart).

$45.8 \%$ of patients in treatment group receiving mutant EGFR tyrosine kinase inhibitors developed rash as compared to only $5.6 \%$ of patients in control group receiving platinum-based chemotherapy. Overall risk ratio of 7.38 with the confidence interval of $95 \%$ was noted which was statistically

Page 2/17 
significant confirming higher rash event rates in patients receiving EGFR inhibitors for their advanced non-small cell lung carcinoma (Table 2A, Figure $-1)$.

$33.6 \%$ of patients in mutant EGFR tyrosine kinase inhibitors treatment group developed diarrhea as compared to $13.5 \%$ of patients in control group receiving platinum-based chemotherapy. Overall risk ratio of 2.63 with the confidence interval of $95 \%$ was noted which was statistically significant confirming higher diarrheal rates in patients receiving EGFR inhibitors for their advanced non-small cell lung carcinoma (Table 2A, Figure 2).

$27.9 \%$ of patients in treatment group receiving mutant EGFR tyrosine kinase inhibitors developed elevated alanine aminotransferase as compared to $15.1 \%$ of patients in control group receiving platinum-based chemotherapy. Overall risk ratio of 1.37 with the confidence interval of $95 \%$ was noted which was statistically significant confirming higher alanine aminotransferase levels in patients receiving EGFR inhibitors for their advanced nonsmall cell lung carcinoma (Table 2A, Figure 3).

$40.7 \%$ of patients in mutant EGFR tyrosine kinase inhibitors treatment group developed elevated aspartate aminotransferase as compared to $12.8 \%$ of patients in control group receiving platinum-based chemotherapy. Overall risk ratio of 1.77 with the confidence interval of $95 \%$ was noted which was statistically significant confirming elevated aspartate aminotransferase levels in patients receiving EGFR inhibitors for their advanced non-small cell lung carcinoma (Table 2A, Figure 4).

$17.2 \%$ of patients in treatment group receiving mutant EGFR tyrosine kinase inhibitors developed stomatitis as compared to $7.9 \%$ of patients in control group receiving platinum-based chemotherapy. Overall risk ratio of 1.53 with the confidence interval of $95 \%$ was noted which was statistically significant confirming higher stomatitis event rates in patients receiving EGFR inhibitors for their advanced non-small cell lung carcinoma (Table 2A, Figure 5).

$16.5 \%$ of patients in mutant EGFR tyrosine kinase inhibitors group developed nausea as compared to $42.5 \%$ of patients in control group receiving platinum-based chemotherapy. Overall risk ratio of 0.37 with the confidence interval of $95 \%$ was noted which was statistically significant confirming higher nausea rates in patients receiving platinum-based chemotherapy as compared to treatment group for their advanced non-small cell lung carcinoma (Table 2A, Figure 6).

9.7\% of patients in mutant EGFR tyrosine kinase inhibitors group developed leucopenia as compared to $51.3 \%$ of patients in control group receiving platinum-based chemotherapy. Overall risk ratio of 0.18 with the confidence interval of $95 \%$ was noted which was statistically significant confirming higher leucopenia incidence in patients receiving platinum-based chemotherapy as compared to treatment group for their advanced non-small cell lung carcinoma (Table 2A, Figure 7).

$17 \%$ of patients in mutant EGFR tyrosine kinase inhibitors group developed fatigue as compared to $29.5 \%$ of patients in control group receiving platinum-based chemotherapy. Overall risk ratio of 0.59 with the confidence interval of $95 \%$ was noted which was statistically significant confirming higher fatigue rates in patients receiving platinum-based chemotherapy as compared to treatment group for their advanced non-small cell lung carcinoma (Table 2B, Figure 8).

$6.1 \%$ of patients in mutant EGFR tyrosine kinase inhibitors group developed neutropenia as compared to $48.2 \%$ of patients in control group receiving platinum-based chemotherapy. Overall risk ratio of 0.11 with the confidence interval of $95 \%$ was noted which was statistically significant confirming higher neutropenia rates in patients receiving platinum-based chemotherapy as compared to treatment group for their advanced non-small cell lung carcinoma (Table 2B, Figure 9).

$21.3 \%$ of patients in mutant EGFR tyrosine kinase inhibitors group developed anorexia as compared to $31.4 \%$ of patients in control group receiving platinum-based chemotherapy. Overall risk ratio of 0.44 with the confidence interval of $95 \%$ was noted which was statistically significant confirming higher anorexia rates in patients receiving platinum-based chemotherapy as compared to treatment group for their advanced non-small cell lung carcinoma (Table 2B, Figure 10).

8.7\% of patients in mutant EGFR tyrosine kinase inhibitors group developed anemia as compared to $32.1 \%$ of patients in control group receiving platinum-based chemotherapy. Overall risk ratio of 0.24 with the confidence interval of $95 \%$ was noted which was statistically significant confirming higher anorexia rates in patients receiving platinum-based chemotherapy as compared to treatment group for their advanced non-small cell lung carcinoma (Table 2B, Figure 11).

$17.8 \%$ of patients in mutant EGFR tyrosine kinase inhibitors group developed cough as compared to $18.9 \%$ of patients in control group receiving platinum-based chemotherapy. Overall risk ratio of 0.99 with the confidence interval of $95 \%$ was noted which was statistically significant confirming slightly higher cough rates in patients receiving platinum-based chemotherapy as compared to treatment group for their advanced non-small cell lung carcinoma (Table 2B, Figure 12).

$11 \%$ of patients in mutant EGFR tyrosine kinase inhibitors group developed vomiting as compared to $30.1 \%$ of patients in control group receiving platinum-based chemotherapy. Overall risk ratio of 0.35 with the confidence interval of $95 \%$ was noted which was statistically significant confirming higher vomiting rates in patients receiving platinum-based chemotherapy as compared to treatment group for their advanced non-small cell lung carcinoma (Table 2B, Figure 13). 
$5.6 \%$ of patients in mutant EGFR tyrosine kinase inhibitors group developed fever as compared to $30.1 \%$ of patients in control group receiving platinum-based chemotherapy. Overall risk ratio of 0.41 with the confidence interval of $95 \%$ was noted which was statistically significant confirming higher fever rates in patients receiving platinum-based chemotherapy as compared to treatment group for their advanced non-small cell lung carcinoma (Table 2B, Figure 14).

\section{Discussion}

Despite the advancement in the treatment of metastatic non-small cell lung cancer. Lung cancer stays as most common cause of cancer related death in North America and European Countries, as patients usually have an advanced disease at the time of diagnosis [3]. In the past, platinumbased chemotherapy remained the standard of care for most patients affected with advanced non-small cell lung cancer (NSCLC) but the higher recurrence rate and increase in frequency and intensity of adverse effects with platinum-based chemotherapy led to the development of targeted therapy for NSCLC, one of which includes mutant EGFR tyrosine kinase inhibitors including Erlotinib, gefitinib, dacomitinib, lapatinib and Osimertinib respectively [4].

Smoking is the most common reversible risk factor associated with lung cancer. EURTAC trial was the first perspective study in this regard which compared safety and efficacy of mutant EGFR tyrosine kinase inhibitors with platinum-based chemotherapy. Results analyzed in this study were in the favor of mutant EGFR tyrosine kinase inhibitors except in the group of former smokers [5]. In contrary, OPTIMAL trial showed results in the favor of mutant EGFR tyrosine kinase inhibitors both in active and former smokers, OPTIMAL trial confirmed the efficacy of mutant EGFR tyrosine kinase inhibitors in European and Asian populations confirming the rationale for routine testing of EGFR mutation in all patients being diagnosed with advanced non-small cell lung carcinoma [6]. Similarly, Osimertinib is one of the most recent mutant EGFR tyrosine kinase inhibitors developed for the treatment of advanced non-small cell lung cancer in patients with EGFR positive receptors. According to FLAURA trial, patients receiving Osimertinib showed significantly longer progression-free survival as compared to platinum-based chemotherapy and ancient mutant EGFR tyrosine kinase inhibitors. Median progression free survival was noted to be 18.9 months which showed $54 \%$ lower risk of disease progression in the treatment group receiving Osimertinib [7]. ARCHER study emphasized on significant improvement in overall survival as well as on progression free survival among patient population receiving Dacomitinib as compared to platinum-based chemotherapy $[8,9]$.

Being a potent-targeted-therapy, mutant EGFR tyrosine kinase inhibitors does come with some adverse effects including diarrhea which was seen in $33.6 \%$ of the patients receiving mutant EGFR tyrosine kinase inhibitors in our study as compared to $53 \%$ in chemotherapy group as was observed in the study conducted by Pless et al [10]. Similarly, only $16.5 \%$ of patients receiving mutant EGFR tyrosine kinase inhibitors developed nausea as compared to $66 \%$ being observed in patients receiving chemotherapy, likewise only a small fraction of patients up to $9.7 \%$ receiving mutant EGFR tyrosine kinase inhibitors developed leucopenia which was ten times less reported in mutant EGFR tyrosine kinase inhibitors as compared to patients receiving chemotherapy having a percentage of $100 \%$. Similar trend was reported for neutropenia and anemia in mutant EGFR tyrosine kinase inhibitors with an incidence of $6.1 \%$ and $8.7 \%$ as compared to platinum-based chemotherapy group having incidence of $80 \%$ and $100 \%$. It was concluded that platinum-based chemotherapy had played a vital role in the treatment of advanced non-small cell lung cancer but at an expense of serious and severe adverse effects which had led to discontinuation or withdrawal of treatment, ultimately leading to relapse and recurrence of lung cancer $[10,11]$.

Zhong et al conducted a phase II randomized clinical trial comparing mutant EGFR tyrosine kinase inhibitors with platinum-based chemotherapy. They concluded that in patients receiving platinum-based chemotherapy incidence of rash, vomiting, anorexia, neutropenia, and nausea were $29.4 \%$, $47 \%, 41.2 \%, 55.8 \%$ and $32.4 \%$ as compared to $45.8 \%, 11 \%, 21.3 \%, 6.1 \%$, and $16.5 \%$ reported in patients receiving mutant EGFR tyrosine kinase inhibitors for their advanced non-small cell lung cancer [12].

Another study was conducted in 2019 by Noronha et al to determine the impact of platinum-based chemotherapy when combined with gefitinib on patients with advanced non-small cell lung cancer. They concluded that $70 \%$ of patients receiving the combination treatment developed rash which was significantly higher as compared to $45.8 \%$ patient receiving mutant EGFR tyrosine kinase inhibitors alone in our study. Also, $56 \%$ of patient receiving combination therapy developed diarrhea as compared to $33.6 \%$ of patients receiving mutant EGFR tyrosine kinase inhibitors as was observed in our study. Similarly, $96 \%$ of patient in combination therapy group develop some degree of anemia as compared to only $8.7 \%$ patients in mutant EGFR tyrosine kinase inhibitors included in our study. Likewise, neutropenia was observed in $55 \%$ of patients receiving combination therapy as compared to $6.1 \%$ in patient receiving mutant EGFR tyrosine kinase inhibitors included in our study. They concluded that mutant EGFR tyrosine kinase inhibitors when combined with platinum-based chemotherapy increase the incidence of adverse effects of chemotherapy by many folds $[13,14]$.

Kato and colleagues conducted a study to determine the impact on adverse effects when erlotinib was combined with anti-VEGF inhibitors like bevacizumab, they stated that $98.7 \%$ of patient in combination therapy developed rash, incidence of which was $45.8 \%$ in patient receiving mutant EGFR tyrosine kinase inhibitors as was observed in our study, Similar kind of trend was noticed with other adverse effects including diarrhea, fatigue, nausea, and elevated liver enzymes respectively [15].

With the latest advancements in the management of advanced non-small cell lung cancer, Nivolumab a programmed death 1 (PD-L1) inhibitors were developed which was either used as monotherapy in patients with PD-L1 expression or was combined with platinum-based chemotherapy regardless

Page 4/17 
of PDL-1 expression [16,17]. Patient expressing lower level of PD-L1 levels weren't omitted from receiving nivolumab as no significant difference was noted in progression free span and overall survival in patients receiving nivolumab irrespective of PD-L1 levels [15]. 17\% of the patients developed rash after receiving nivolumab as compared to $45.8 \%$ patients being observed in our study, Similar trend was observed with diarrhea as only $17 \%$ of the population receiving nivolumab developed diarrhea as compared to $33.6 \%$ of population receiving mutant EGFR tyrosine kinase inhibitors in our study. Likewise, only $9.9 \%$ of the patient receiving nivolumab developed nausea as an adverse effect as compared $16.5 \%$ being observed in mutant EGFR tyrosine kinase inhibitors in our study. Also, fatigue was observed in $14.4 \%$ of population receiving nivolumab as compared to $17 \%$ observed in patients receiving mutant EGFR tyrosine kinase inhibitors as was noticed in our study $[7,8]$. Rizvi etal conducted a study on role of nivolumab when combined with platinum-based chemotherapy in patient with advanced non-small cell lung cancer and reported that $40 \%$ of patients included in the study developed rash as compared to $45.8 \%$ reported in mutant EGFR tyrosine kinase inhibitors being studied in our study. Similarly, only $13 \%$ of patient in nivolumab group developed diarrhea as compared to $33.6 \%$ cases reported in mutant EGFR tyrosine kinase inhibitors group included in our study. Also, $7 \%$ of patient in nivolumab group developed elevated alanine aminotransferase as compared to $27.9 \%$ of patients receiving mutant EGFR tyrosine kinase inhibitors included in our study concluding that addition of immune-check point inhibitors like nivolumab to platinum-based chemotherapy doesn't increase the frequency of adverse effects [18].

\section{Conclusion}

Our study focused on the safety profile of mutant EGFR tyrosine kinase inhibitors as compared to platinum-based chemotherapy in the treatment of advanced non-small cell lung cancer. mutant EGFR tyrosine kinase inhibitors are safer as compared to platinum-based chemotherapy when compared for nausea, leucopenia, fatigue, neutropenia, anorexia, anemia, cough, vomiting and fever. On the other end, mutant EGFR tyrosine kinase inhibitors causes slightly higher adverse effects including rash, diarrhea, elevated aspartate aminotransferase, elevated alanine aminotransferase and stomatitis but considering that, development of mutant EGFR tyrosine kinase inhibitors laid a foundation of targeted therapy, we recommend continuing using mutant EGFR tyrosine kinase inhibitors in patient with advanced non-small cell lung cancer especially in patient having mutant EGFR tyrosine kinase inhibitors. Adverse effects caused by mutant EGFR tyrosine kinase inhibitors are significant but are usually tolerable and can be avoided by reducing the dosage of it with each cycle or by skipping or delaying the dose till patient is symptomatic.

\section{Declarations}

\section{Conflict of Interest:}

There were no financial or non-financial conflicts noticed or witnessed among all the authors of the manuscript part of the submitted project.

\section{Disclosure and Declaration Statement:}

There were no human and animal subjects included in the study

\section{References}

1. Rahib L, Smith BD, Aizenberg R, et al. Projecting cancer incidence and deaths to 2030: the unexpected burden of thyroid, liver, and pancreas cancers in the United States. Cancer Res. 2014 Jun 1;74(11):2913-21.

2. da Cunha Santos G, Shepherd FA, Tsao MS. EGFR mutations and lung cancer. Annu Rev Pathol. 2011;6:49-69.

3. Sgambato A, Casaluce F, Maione P, et al. The role of EGFR tyrosine kinase inhibitors in the first-line treatment of advanced non small cell lung cancer patients harboring EGFR mutation. Curr Med Chem. 2012;19(20):3337-52.

4. Rossi A, Di Maio M. Platinum-based chemotherapy in advanced non-small-cell lung cancer: optimal number of treatment cycles. Expert Rev Anticancer Ther. 2016 Jun;16(6):653-60.

5. Rosell, R., Carcereny, E., Gervais, R., et al. Erlotinib versus standard chemotherapy as first-line treatment for European patients with advanced EGFR mutation-positive non-small-cell lung cancer (EURTAC): a multicentre, open-label, randomised phase 3 trial. The Lancet Oncology, 13(3), 239-246.

6. Zhou C, Wu Y-L, Chen G, et al. Erlotinib versus chemotherapy as first-line treatment for patients with advanced EGFR mutation-positive non-smallcell lung cancer (OPTIMAL, CTONG-0802): a multicenter, open-label, randomized, phase 3 study. Lancet Oncol 2011; 12: 735-42

7. Soria, J.-C., Ohe, Y., Vansteenkiste, J., et al. Osimertinib in Untreated EGFR-Mutated Advanced Non-Small-Cell Lung Cancer. New England Journal of Medicine, 378(2), 113-125.

8. Mok, T. S., Cheng, Y., Zhou, X., et al. Improvement in Overall Survival in a Randomized Study That Compared Dacomitinib With Gefitinib in Patients With Advanced Non-Small-Cell Lung Cancer and EGFR-Activating Mutations. Journal of Clinical Oncology, 36(22), 2244-2250.

9. Mok TS, Wu YL, Thongprasert S, et al: Gefitinib or carboplatin-paclitaxel in pulmonary adenocarcinoma. N Engl J Med 361:947-957, 2009.

10. Pless M, Stupp R, Ris HB, et al. Induction chemoradiation in stage IIIA/N2 non-small-cell lung cancer: a phase 3 randomised trial. Lancet. 2015 Sep 12;386(9998):1049-56. 
11. Albain KS, Rusch VW, Crowley JJ, et al. Concurrent cisplatin/ etoposide plus chest radiotherapy followed by surgery for stages IIIA (N2) and IIIB non-small-cell lung cancer: mature results of Southwest Oncology Group phase II study 8805. J Clin Oncol 1995; 13: 1880-92.

12. Zhong, W.-Z., Chen, K.-N., Chen, et al. Erlotinib Versus Gemcitabine Plus Cisplatin as Neoadjuvant Treatment of Stage IIIA-N2 EGFR-Mutant NonSmall-Cell Lung Cancer (EMERGING-CTONG 1103): A Randomized Phase II Study. Journal of Clinical Oncology, JCO.19.00075.

13. Noronha, V., Patil, V. M., Joshi, A., et al. Gefitinib Versus Gefitinib Plus Pemetrexed and Carboplatin Chemotherapy in EGFR-Mutated Lung Cancer. Journal of Clinical Oncology, JCO.19.01154.

14. Noronha V, Prabhash K, Thavamani A, et al: EGFR mutations in Indian lung cancer patients: Clinical correlation and outcome to EGFR targeted therapy. PLoS One 8:e61561, 2013.

15. Kato, T., Seto, T., Nishio, M., et al. Erlotinib Plus Bevacizumab Phase Il Study in Patients with Advanced Non-small-Cell Lung Cancer (J025567): Updated Safety Results. Drug Safety, 41(2), 229-237.

16. Hellmann, M. D., Paz-Ares, L., Bernabe Caro, R., et al. Nivolumab plus Ipilimumab in Advanced Non-Small-Cell Lung Cancer. New England Journal of Medicine, 381(21), 2020-2031.

17. Hellmann MD, Ciuleanu TE, Pluzanski A, et al. Nivolumab plus ipilimumab in lung cancer with a high tumor mutational burden. $\mathrm{N}$ Engl $\mathrm{J}$ Med 2018;378:2093-104.

18. Rizvi, N. A., Hellmann, M. D., Brahmer, et al. Nivolumab in Combination With Platinum-Based Doublet Chemotherapy for First-Line Treatment of Advanced Non-Small-Cell Lung Cancer. Journal of Clinical Oncology, 34(25), 2969-2979.

\section{Tables}

Table 1: Study characteristics including in our meta-analysis.

\begin{tabular}{|c|c|c|c|c|c|c|}
\hline Study & Trial Name & $\begin{array}{l}\text { Publication } \\
\text { year }\end{array}$ & Design & Country & $\begin{array}{l}\text { Treatment } \\
\text { group }\end{array}$ & Control group \\
\hline Zhong et al & $\begin{array}{l}\text { ADJUVANT/CTONG1104 } \\
\text { trial }\end{array}$ & 2018 & $\begin{array}{l}\text { Phase } 3 \\
\text { Randomized } \\
\text { control trial }\end{array}$ & China & $\begin{array}{l}\text { EGFR } \\
\text { inhibitors }\end{array}$ & $\begin{array}{l}\text { Platinum based } \\
\text { chemotherapy }\end{array}$ \\
\hline $\begin{array}{l}\text { Wu et } \\
\text { al }\end{array}$ & LUX LUNG 6 trial & 2018 & $\begin{array}{l}\text { Phase } 3 \\
\text { randomized } \\
\text { control trial }\end{array}$ & China & $\begin{array}{l}\text { EGFR } \\
\text { inhibitors }\end{array}$ & $\begin{array}{l}\text { Platinum based } \\
\text { chemotherapy }\end{array}$ \\
\hline Shi et al & CONVINCE trial & 2017 & $\begin{array}{l}\text { Phase } 3 \\
\text { randomized } \\
\text { control trial }\end{array}$ & $\begin{array}{l}\text { USA } \\
\text { China } \\
\text { Middle East }\end{array}$ & $\begin{array}{l}\text { EGFR } \\
\text { inhibitors }\end{array}$ & $\begin{array}{l}\text { Platinum based } \\
\text { chemotherapy }\end{array}$ \\
\hline Soria et al & Impress trial & 2015 & $\begin{array}{l}\text { Phase } 3 \\
\text { randomized } \\
\text { control trial }\end{array}$ & $\begin{array}{l}\text { Europe and the Asia- } \\
\text { Pacific region }\end{array}$ & $\begin{array}{l}\text { EGFR } \\
\text { inhibitors }\end{array}$ & $\begin{array}{l}\text { Platinum based } \\
\text { chemotherapy }\end{array}$ \\
\hline Goss et al & NCIC CTG BR19 trial & 2013 & $\begin{array}{l}\text { Phase } 3 \\
\text { randomized } \\
\text { control trial }\end{array}$ & $\begin{array}{l}\text { USA } \\
\text { Asia pacific } \\
\text { Europe }\end{array}$ & $\begin{array}{l}\text { EGFR } \\
\text { inhibitors }\end{array}$ & $\begin{array}{l}\text { Platinum based } \\
\text { chemotherapy }\end{array}$ \\
\hline $\begin{array}{l}\text { Mu Sun et } \\
\text { al }\end{array}$ & KCSG-LU08-01 trial & 2012 & $\begin{array}{l}\text { Phase } 3 \\
\text { randomized } \\
\text { control trial }\end{array}$ & $\begin{array}{l}\text { USA } \\
\text { Asia pacific } \\
\text { Europe }\end{array}$ & $\begin{array}{l}\text { EGFR } \\
\text { inhibitors }\end{array}$ & $\begin{array}{l}\text { Platinum based } \\
\text { chemotherapy }\end{array}$ \\
\hline $\begin{array}{l}\text { Mitsudomi } \\
\text { et al }\end{array}$ & WJTOG3405 trial & 2011 & $\begin{array}{l}\text { Phase } 3 \\
\text { randomized } \\
\text { control trial }\end{array}$ & Japan & $\begin{array}{l}\text { EGFR } \\
\text { inhibitors }\end{array}$ & $\begin{array}{l}\text { Platinum based } \\
\text { chemotherapy }\end{array}$ \\
\hline Lee et al & Istana trial & 2010 & $\begin{array}{l}\text { Phase } 3 \\
\text { randomized } \\
\text { control trial }\end{array}$ & $\begin{array}{l}\text { USA } \\
\text { Middle East } \\
\text { Australia }\end{array}$ & $\begin{array}{l}\text { EGFR } \\
\text { inhibitors }\end{array}$ & $\begin{array}{l}\text { Platinum based } \\
\text { chemotherapy }\end{array}$ \\
\hline Kim et al & Interest trial & 2008 & $\begin{array}{l}\text { Phase } 3 \\
\text { randomized } \\
\text { control trial }\end{array}$ & Japan & $\begin{array}{l}\text { EGFR } \\
\text { inhibitors }\end{array}$ & $\begin{array}{l}\text { Platinum based } \\
\text { chemotherapy }\end{array}$ \\
\hline
\end{tabular}

TABLE 2A: Adverse effects included in our meta-analysis: 


\begin{tabular}{|c|c|c|c|c|c|c|c|c|}
\hline Study/Trial name & $\begin{array}{l}\text { Treatment/ } \\
\text { Control } \\
\text { group }\end{array}$ & Rash & Diarrhea & $\begin{array}{l}\text { Elevated } \\
\text { ALT }\end{array}$ & $\begin{array}{l}\text { Elevated } \\
\text { AST }\end{array}$ & Stomatitis & Nausea & Leucopenia \\
\hline \multirow{2}{*}{$\begin{array}{l}\text { Zhong et } \\
\text { al/ ADJUVANT/CTONG1104 } \\
\text { trial }\end{array}$} & $\begin{array}{l}\text { Treatment } \\
\text { group }\end{array}$ & $43(40.6 \%)$ & $28(26.4 \%)$ & $29(27.4 \%)$ & $12(11.3 \%)$ & $8(7.5 \%)$ & $3(2.8 \%)$ & $4(3.7 \%)$ \\
\hline & $\begin{array}{l}\text { Control } \\
\text { group }\end{array}$ & $0(0 \%)$ & $4(4.6 \%)$ & $3(3.5 \%)$ & $1(1.2 \%)$ & $5(5.7 \%)$ & $38(43.7 \%)$ & $41(47 \%)$ \\
\hline \multirow[t]{2}{*}{ Wu et al/ LUX LUNG 6 trial } & $\begin{array}{l}\text { Treatment } \\
\text { group }\end{array}$ & $144(82.3 \%)$ & $153(87.4 \%)$ & $39(22.3 \%)$ & $32(18.3 \%)$ & $88(50.3 \%)$ & $11(6.3 \%)$ & $5(2.8 \%)$ \\
\hline & $\begin{array}{l}\text { Control } \\
\text { group }\end{array}$ & $9(9.5 \%)$ & $10(10.5 \%)$ & $16(17 \%)$ & $10(10.5 \%)$ & $5(5.3 \%)$ & $72(75.8 \%)$ & $53(55.8 \%)$ \\
\hline \multirow[t]{2}{*}{ Shi et al/CONVINCE trial } & $\begin{array}{l}\text { Treatment } \\
\text { group }\end{array}$ & $22(15 \%)$ & $11(7.4 \%)$ & $10(6.7 \%)$ & $12(81 \%)$ & - & $4(2.7 \%)$ & $11(7.4 \%)$ \\
\hline & $\begin{array}{l}\text { Control } \\
\text { group }\end{array}$ & $2(1.5 \%)$ & $6(4.3 \%)$ & $19(13.9 \%)$ & $15(11 \%)$ & - & $63(46 \%)$ & $60(43.8 \%)$ \\
\hline \multirow[t]{2}{*}{ Soria et al/ Impress trial } & $\begin{array}{l}\text { Treatment } \\
\text { group }\end{array}$ & $14(11 \%)$ & $44(33.3 \%)$ & $17(12.9 \%)$ & $30(22.7 \%)$ & $14(10.6 \%)$ & $85(64.4 \%)$ & $27(20.5 \%)$ \\
\hline & $\begin{array}{l}\text { Control } \\
\text { group }\end{array}$ & $11(8 \%)$ & $19(14.9 \%)$ & $23(17 \%)$ & $29(22 \%)$ & $5(3.7 \%)$ & $81(61.4 \%)$ & $22(16.7 \%)$ \\
\hline \multirow[t]{2}{*}{$\begin{array}{l}\text { Goss et al/ NCIC CTG BR19 } \\
\text { trial }\end{array}$} & $\begin{array}{l}\text { Treatment } \\
\text { group }\end{array}$ & $21(8.5 \%)$ & $18(7.2 \%)$ & - & - & - & $6(2.4 \%)$ & - \\
\hline & $\begin{array}{l}\text { Control } \\
\text { group }\end{array}$ & $1(0.5 \%)$ & $5(2 \%)$ & - & - & - & $1(0.4 \%)$ & - \\
\hline \multirow[t]{2}{*}{$\begin{array}{l}\text { Mu Sen et al/ KCSG-LU08-01 } \\
\text { trial }\end{array}$} & $\begin{array}{l}\text { Treatment } \\
\text { group }\end{array}$ & $31(46 \%)$ & $18(26 \%)$ & - & - & - & $11(16.2 \%)$ & - \\
\hline & $\begin{array}{l}\text { Control } \\
\text { group }\end{array}$ & $3(4.5 \%)$ & $3(4.4 \%)$ & - & - & - & $11(16.4 \%)$ & - \\
\hline \multirow[t]{2}{*}{$\begin{array}{l}\text { Mitsudomi et } \\
\text { al/ WJTOG3405 trial }\end{array}$} & $\begin{array}{l}\text { Treatment } \\
\text { group }\end{array}$ & $74(85 \%)$ & $47(54 \%)$ & $61(70 \%)$ & $61(70 \%)$ & $19(21.8 \%)$ & $15(17.2 \%)$ & $13(14.9 \%)$ \\
\hline & $\begin{array}{l}\text { Control } \\
\text { group }\end{array}$ & $7(8 \%)$ & $35(40 \%)$ & $35(40 \%)$ & 17(19.3\%) & $13(14.7 \%)$ & $83(94 \%)$ & $82(93.2 \%)$ \\
\hline \multirow[t]{2}{*}{ Lee et al/Istana trial } & $\begin{array}{l}\text { Treatment } \\
\text { group }\end{array}$ & $61(75 \%)$ & $21(26 \%)$ & - & - & $3(3.7 \%)$ & $13(16 \%)$ & - \\
\hline & $\begin{array}{l}\text { Control } \\
\text { group }\end{array}$ & $6(8 \%)$ & $12(15.7 \%)$ & - & - & $9(1.8 \%)$ & $14(18.4 \%)$ & - \\
\hline \multirow[t]{2}{*}{ Kim et al/Interest trial } & $\begin{array}{l}\text { Treatment } \\
\text { group }\end{array}$ & $360(49 \%)$ & $255(35 \%)$ & - & - & $67(9.2 \%)$ & $148(20.3 \%)$ & - \\
\hline & $\begin{array}{l}\text { Control } \\
\text { group }\end{array}$ & 73(10.3\%) & $177(24.7 \%)$ & - & - & $93(13 \%)$ & $187(26.2 \%)$ & - \\
\hline
\end{tabular}

TABLE 2B: Adverse effects included in our meta-analysis:

Figures 


\begin{tabular}{|c|c|c|c|c|c|c|c|c|}
\hline Study/Trial name & $\begin{array}{l}\text { Treatment/ } \\
\text { Control } \\
\text { group }\end{array}$ & Fatigue & Neutropenia & Anorexia & Anemia & Cough & Vomiting & Fever \\
\hline \multirow{2}{*}{$\begin{array}{l}\text { Zhong et } \\
\text { al/ ADJUVANT/CTONG1104 } \\
\text { trial }\end{array}$} & $\begin{array}{l}\text { Treatment } \\
\text { group }\end{array}$ & $4(3.7 \%)$ & $3(2.9 \%)$ & $2(1.8 \%)$ & $2(1.8 \%)$ & $11(10.4 \%)$ & $5(4.7 \%)$ & $1(0.9 \%)$ \\
\hline & $\begin{array}{l}\text { Control } \\
\text { group }\end{array}$ & $4(4.6 \%)$ & $46(52.9 \%)$ & $20(23 \%)$ & $44(50.6 \%)$ & $15(17.2 \%)$ & $36(41.4 \%)$ & $9(10.3 \%)$ \\
\hline \multirow[t]{2}{*}{ Wu et al/ LUX LUNG 6 trial } & $\begin{array}{l}\text { Treatment } \\
\text { group }\end{array}$ & $14(8 \%)$ & $3(1.7 \%)$ & $11(6.3 \%)$ & $9(5.2 \%)$ & - & $14(8 \%)$ & - \\
\hline & $\begin{array}{l}\text { Control } \\
\text { group }\end{array}$ & $37(39 \%)$ & $53(55.8 \%)$ & $39(41 \%)$ & $26(27.4 \%)$ & - & $75(78.9 \%)$ & - \\
\hline \multirow[t]{2}{*}{ Shi et al/CONVINCE trial } & $\begin{array}{l}\text { Treatment } \\
\text { group }\end{array}$ & $5(3.4 \%)$ & $5(3.4 \%)$ & $3(2 \%)$ & $4(2.7 \%)$ & $2(1.4 \%)$ & $2(1.4 \%)$ & $0(0 \%)$ \\
\hline & $\begin{array}{l}\text { Control } \\
\text { group }\end{array}$ & $20(14.6 \%)$ & $58(42.3 \%)$ & $32(23.4 \%)$ & $17(12.4 \%)$ & $3(2.2 \%)$ & $40(29.2 \%)$ & $4(2.9 \%)$ \\
\hline \multirow[t]{2}{*}{ Soria et al/ Impress trial } & $\begin{array}{l}\text { Treatment } \\
\text { group }\end{array}$ & $28(21.2 \%)$ & $29(22 \%)$ & $65(49.2 \%)$ & $0(0 \%)$ & $18(13.6 \%)$ & $55(41.6 \%)$ & $22(16.7 \%)$ \\
\hline & $\begin{array}{l}\text { Control } \\
\text { group }\end{array}$ & $23(17.4 \%)$ & $28(21.2 \%)$ & $45(34.1 \%)$ & $1(0.7 \%)$ & $15(11.4 \%)$ & $44(33.3 \%)$ & $14(10.6 \%)$ \\
\hline \multirow[t]{2}{*}{$\begin{array}{l}\text { Goss et al/ NCIC CTG BR19 } \\
\text { trial }\end{array}$} & $\begin{array}{l}\text { Treatment } \\
\text { group }\end{array}$ & $15(6 \%)$ & - & - & - & - & $3(1.2 \%)$ & - \\
\hline & $\begin{array}{l}\text { Control } \\
\text { group }\end{array}$ & $6(2.5 \%)$ & - & - & - & - & $0(0 \%)$ & - \\
\hline \multirow[t]{2}{*}{$\begin{array}{l}\text { Mu Sen et al/ KCSG-LU08- } \\
01 \text { trial }\end{array}$} & $\begin{array}{l}\text { Treatment } \\
\text { group }\end{array}$ & $15(22.1 \%)$ & $0(0 \%)$ & $22(32.4 \%)$ & - & $25(36.7 \%)$ & - & - \\
\hline & $\begin{array}{l}\text { Control } \\
\text { group }\end{array}$ & $14(21 \%)$ & $1(1.5 \%)$ & $20(29.8 \%)$ & - & $24(35.8 \%)$ & - & - \\
\hline \multirow[t]{2}{*}{$\begin{array}{l}\text { Mitsudomi et } \\
\text { al/ WJTOG3405 trial }\end{array}$} & $\begin{array}{l}\text { Treatment } \\
\text { group }\end{array}$ & $34(39.1 \%)$ & $7(8.1 \%)$ & - & $33(37.9 \%)$ & - & - & - \\
\hline & $\begin{array}{l}\text { Control } \\
\text { group }\end{array}$ & $73(82.9 \%)$ & $81(92 \%)$ & - & 79(89.7\%) & - & - & - \\
\hline \multirow[t]{2}{*}{ Lee et al/Istana trial } & $\begin{array}{l}\text { Treatment } \\
\text { group }\end{array}$ & $20(24.7 \%)$ & - & $29(35.8 \%)$ & - & $25(30.8 \%)$ & $4(4.9 \%)$ & $4(4.9 \%)$ \\
\hline & $\begin{array}{l}\text { Control } \\
\text { group }\end{array}$ & $28(36.9 \%)$ & - & $36(47.4 \%)$ & - & $25(32.9 \%)$ & $8(10.5 \%)$ & $8(10.5 \%)$ \\
\hline \multirow[t]{2}{*}{ Kim et al/Interest trial } & $\begin{array}{l}\text { Treatment } \\
\text { group }\end{array}$ & $182(25 \%)$ & $35(4.8 \%)$ & $159(21.8 \%)$ & $34(4.7 \%)$ & $108(14.8 \%)$ & $109(15 \%)$ & - \\
\hline & $\begin{array}{l}\text { Control } \\
\text { group }\end{array}$ & $334(46.7 \%)$ & $514(72 \%)$ & $151(21.2 \%)$ & $84(11.7 \%)$ & $102(14.3 \%)$ & $123(17.2 \%)$ & - \\
\hline
\end{tabular}




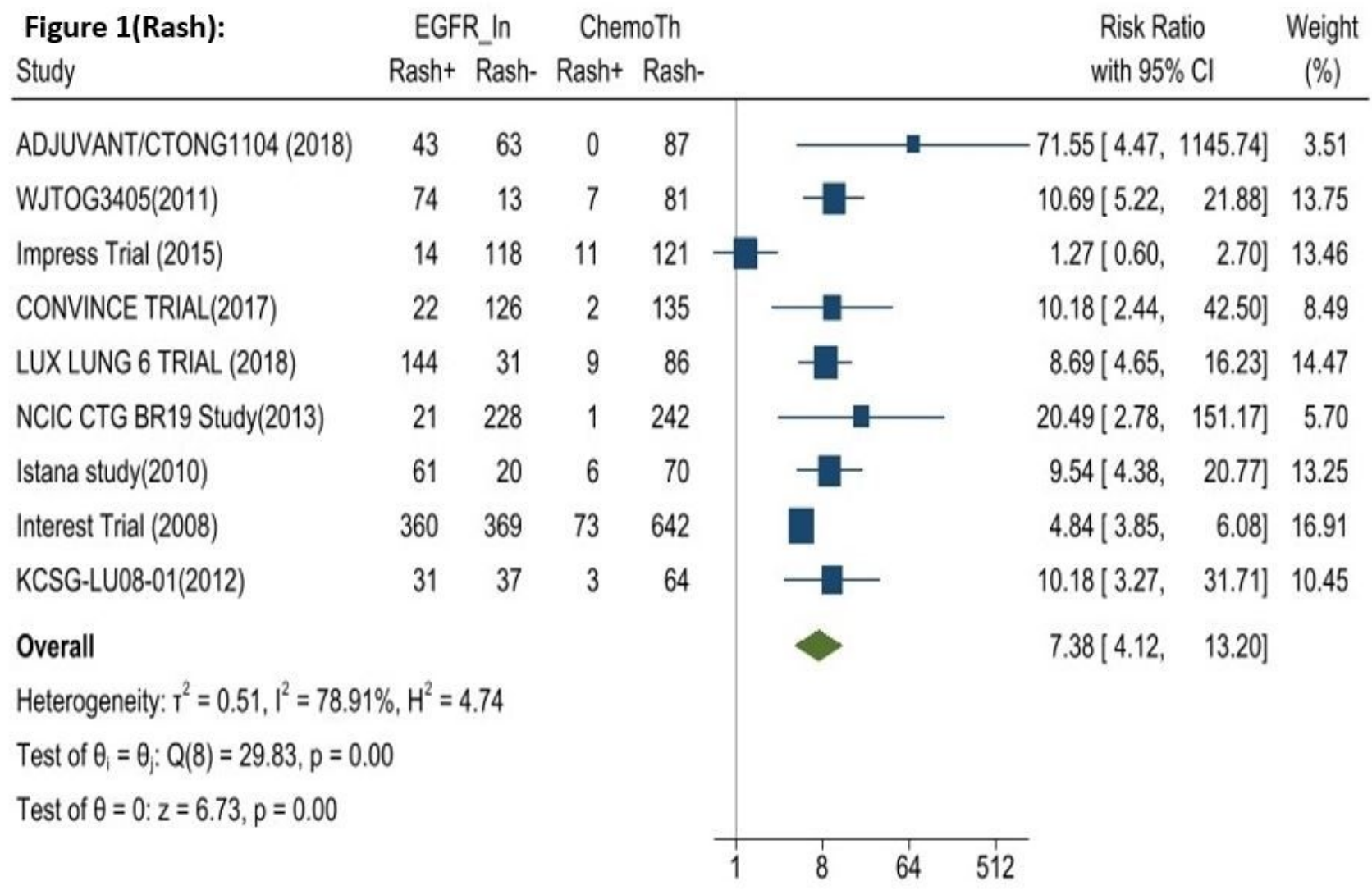

Random-effects REML model

\section{Figure 1}

The risk ratio above 1 indicates higher rash event rates in the EGFR inhibitor group compared to the Chemotherapy group. 


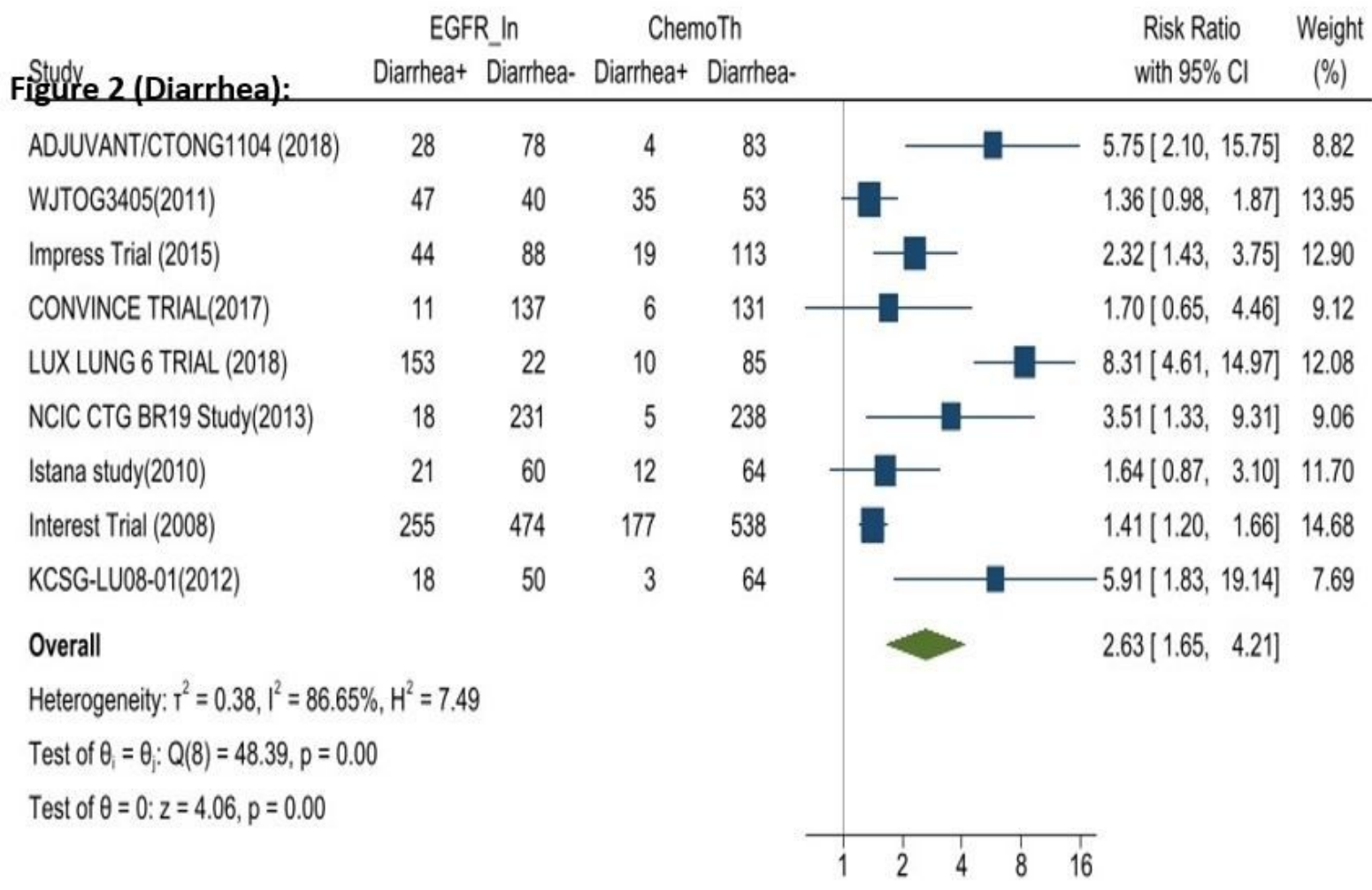

Random-effects REML model

\section{Figure 2}

The risk ratio above 1 indicates higher Diarrhea event rates in the EGFR inhibitor group compared to the Chemotherapy group 


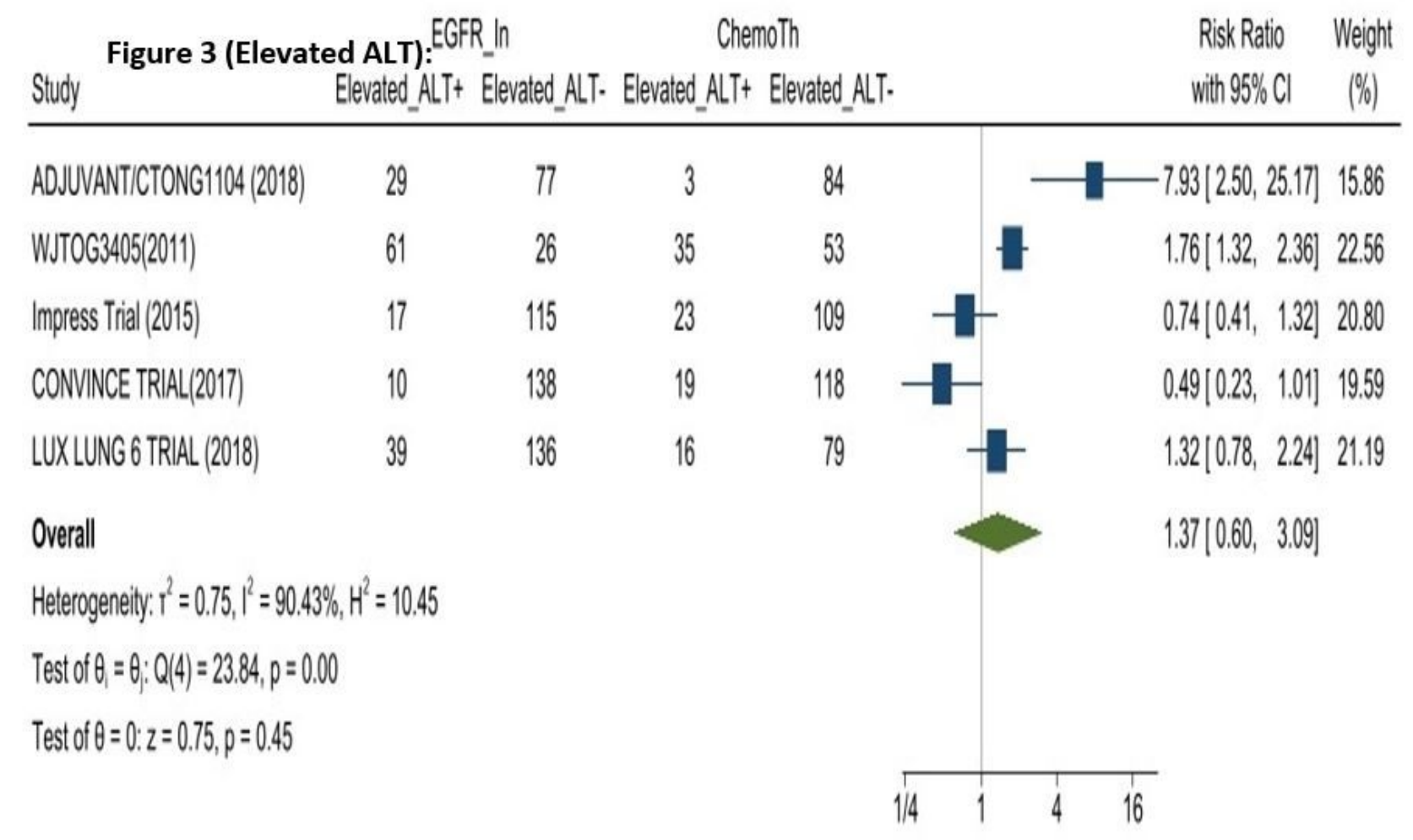

Random-effects REML model

\section{Figure 3}

The risk ratio above 1 indicates higher elevated ALT event rates in the EGFR inhibitor group compared to the Chemotherapy group. 
EGFR_In ChemoTh Risk Ratio Weight

Studfigure 4 (Elevated ASTllivated_AST+ Elevated_AST. Elevated__ST+ Elevated_AST. $\quad$ with $95 \%$ Cl $\quad(\%)$

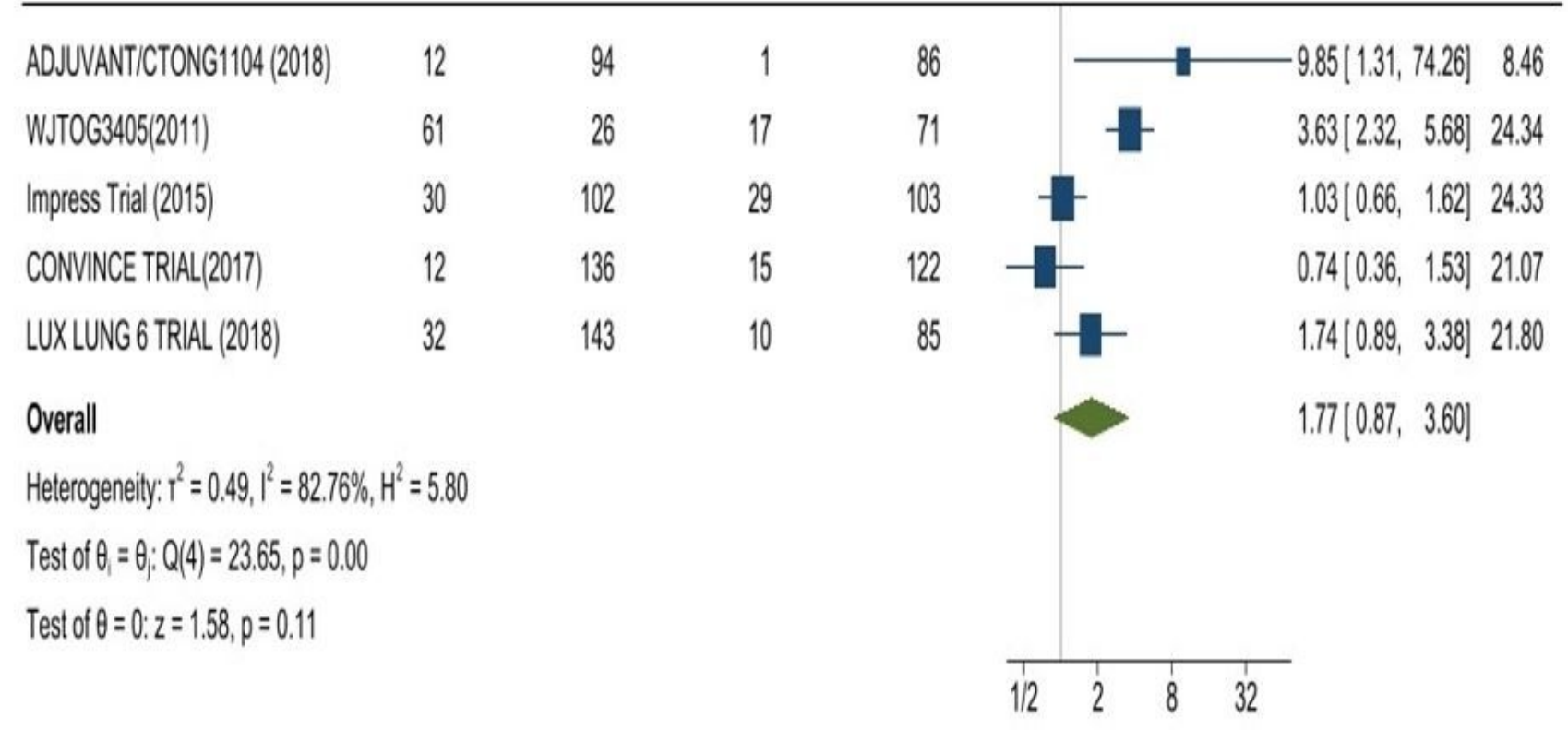

Random-effects REML model

\section{Figure 4}

The risk ratio above 1 indicates higher elevated AST event rates in the EGFR inhibitor group compared to the Chemotherapy group. 


\begin{tabular}{|c|c|c|c|c|c|c|}
\hline \multirow{3}{*}{$\begin{array}{l}\text { Study } \\
\text { Figure 5 (Stomatitis): } \\
\text { ADJUVANT/CTONG1104 (2018) }\end{array}$} & \multicolumn{2}{|c|}{ EGFR_In } & \multicolumn{2}{|c|}{ ChemoTh } & \multirow{2}{*}{$\begin{array}{l}\text { Risk Ratio } \\
\text { with } 95 \% \mathrm{Cl}\end{array}$} & \multirow{2}{*}{$\begin{array}{c}\text { Weight } \\
(\%)\end{array}$} \\
\hline & Nauseat & Nausea- & Nausea+ & Nausea- & & \\
\hline & 3 & 103 & 38 & 49 & $0.06\left[\begin{array}{ll}0.02, & 0.20\end{array}\right]$ & 10.41 \\
\hline WJTOG3405(2011) & 15 & 72 & 83 & 5 & $0.18[0.12,0.29]$ & 11.96 \\
\hline Impress Trial (2015) & 85 & 47 & 81 & 51 & $1.05[0.87,1.26]$ & 12.27 \\
\hline CONVINCE TRIAL(2017) & 4 & 144 & 63 & 74 & $0.06\left[\begin{array}{ll}0.02, & 0.16\end{array}\right]$ & 10.84 \\
\hline LUX LUNG 6 TRIAL (2018) & 11 & 164 & 72 & 23 & $0.08[0.05,0.15]$ & 11.76 \\
\hline NCIC CTG BR19 Study(2013) & 6 & 243 & 1 & 242 & $-5.86[0.71,48.28]$ & 7.56 \\
\hline Istana study(2010) & 13 & 68 & 14 & 62 & $0.87[0.44,1.73]$ & 11.55 \\
\hline Interest Trial (2008) & 148 & 581 & 187 & 528 & $0.78[0.64,0.94]$ & 12.26 \\
\hline KCSG-LU08-01(2012) & 11 & 57 & 11 & 56 & $0.99[0.46,2.12]$ & 11.38 \\
\hline Overall & & & & & $0.37[0.15,0.94]$ & \\
\hline 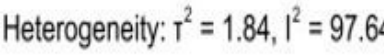 & $\because$ & & & & & \\
\hline
\end{tabular}

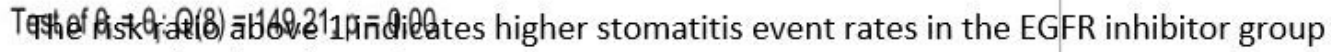

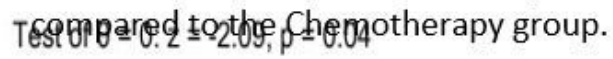

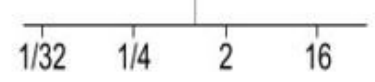

Random-effects REML model

Figure 5

The risk ratio above 1 indicates higher stomatitis event rates in the EGFR inhibitor group compared to the Chemotherapy group.

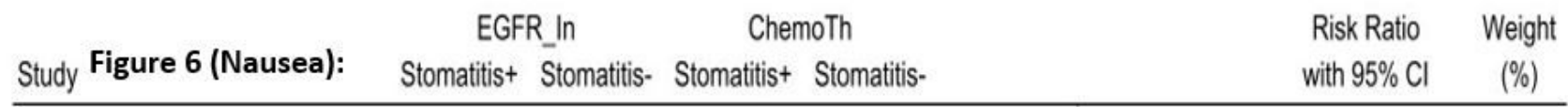

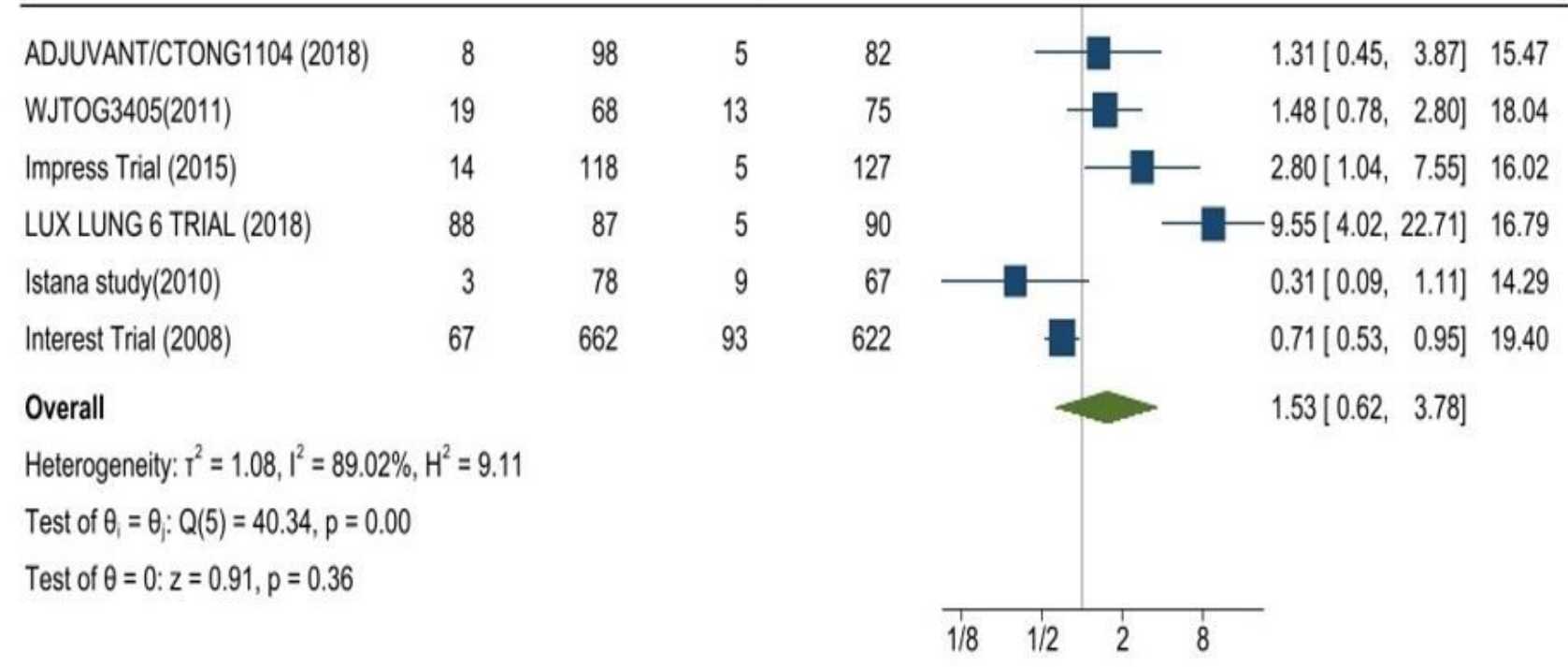

Random-effects REML model

Figure 6

The risk ratio above 1 indicates higher nausea event rates in the EGFR inhibitor group compared to the Chemotherapy group. 


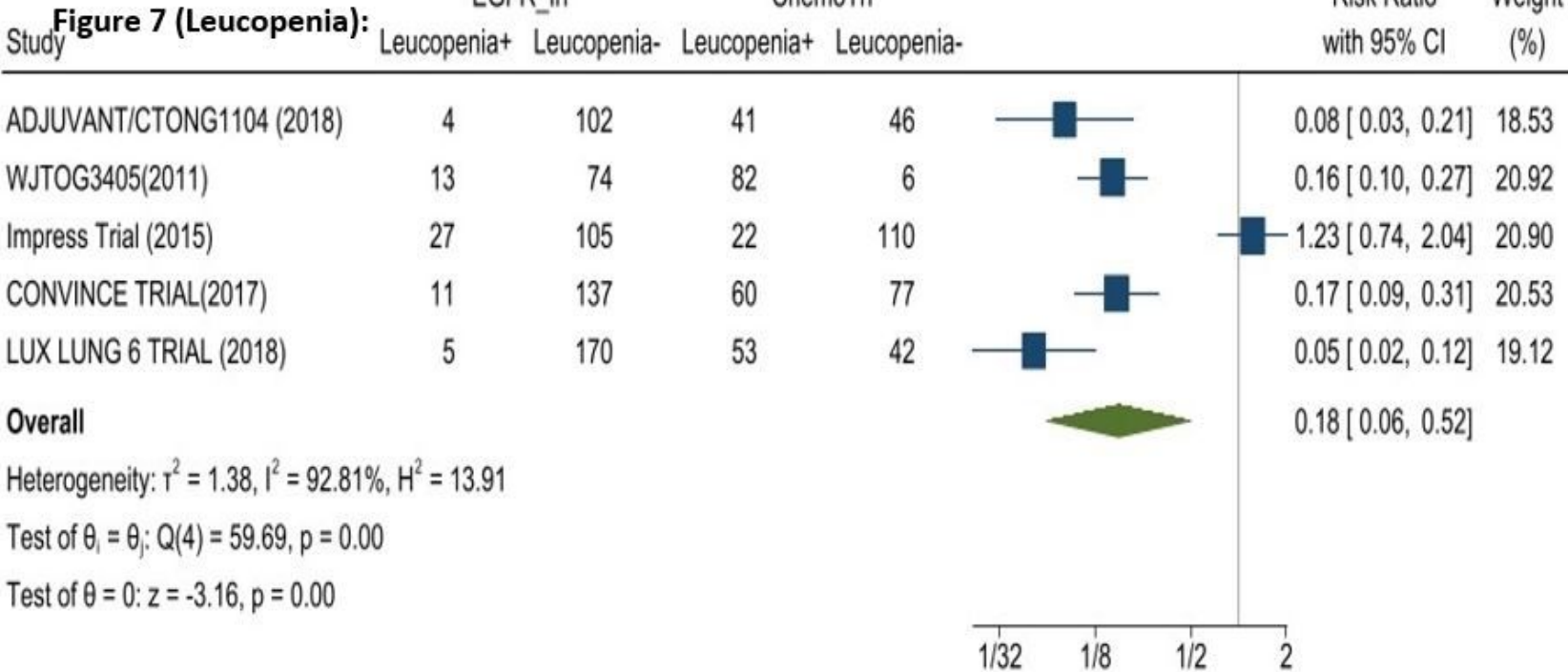

Random-effects REML model

Figure 7

The risk ratio above 1 indicates higher leucopenia event rates in the EGFR inhibitor group compared to the Chemotherapy group.

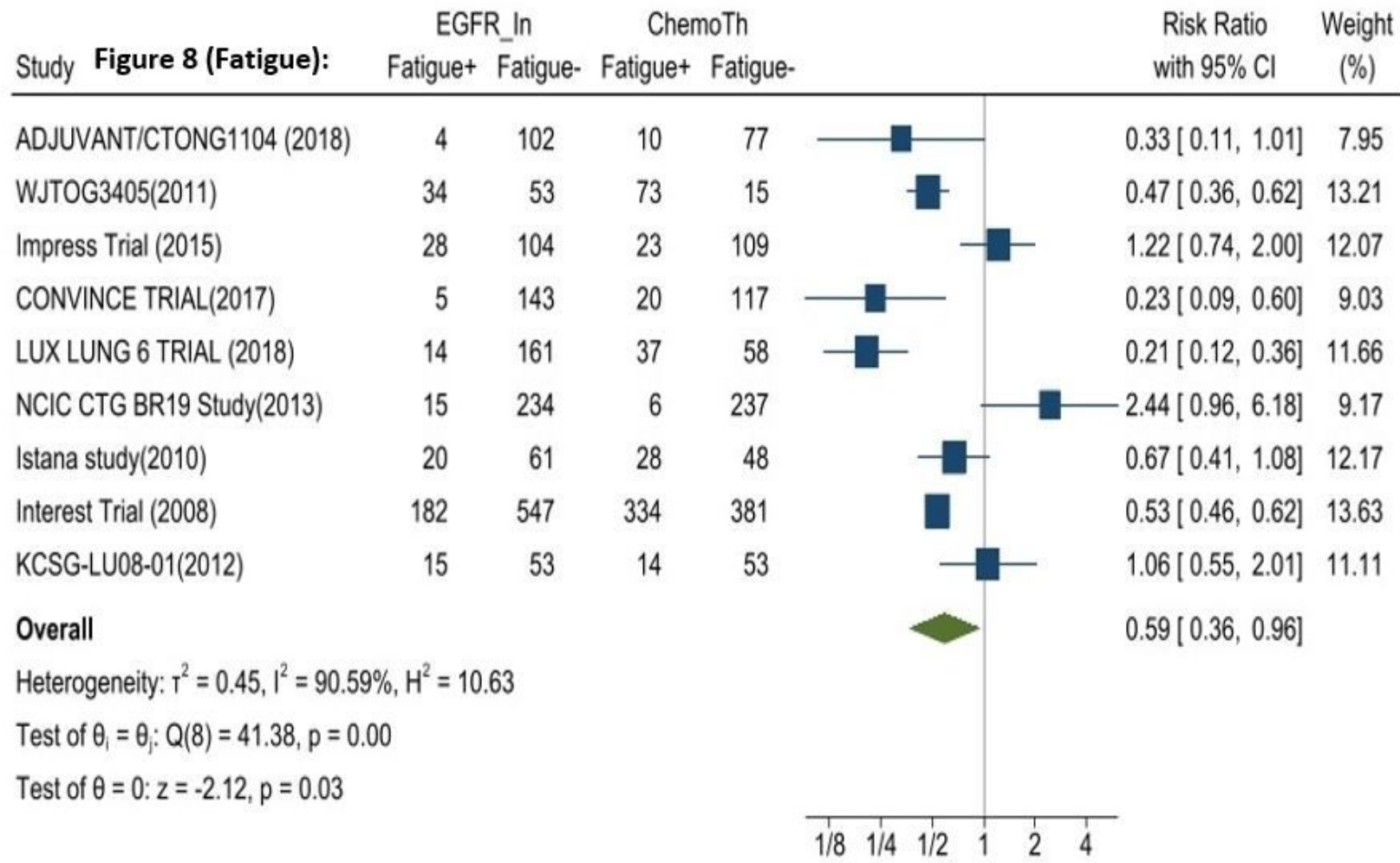

Random-effects REML model

\section{Figure 8}

The risk ratio above 1 indicates higher fatigue event rates in the EGFR inhibitor group compared to the Chemotherapy group. 


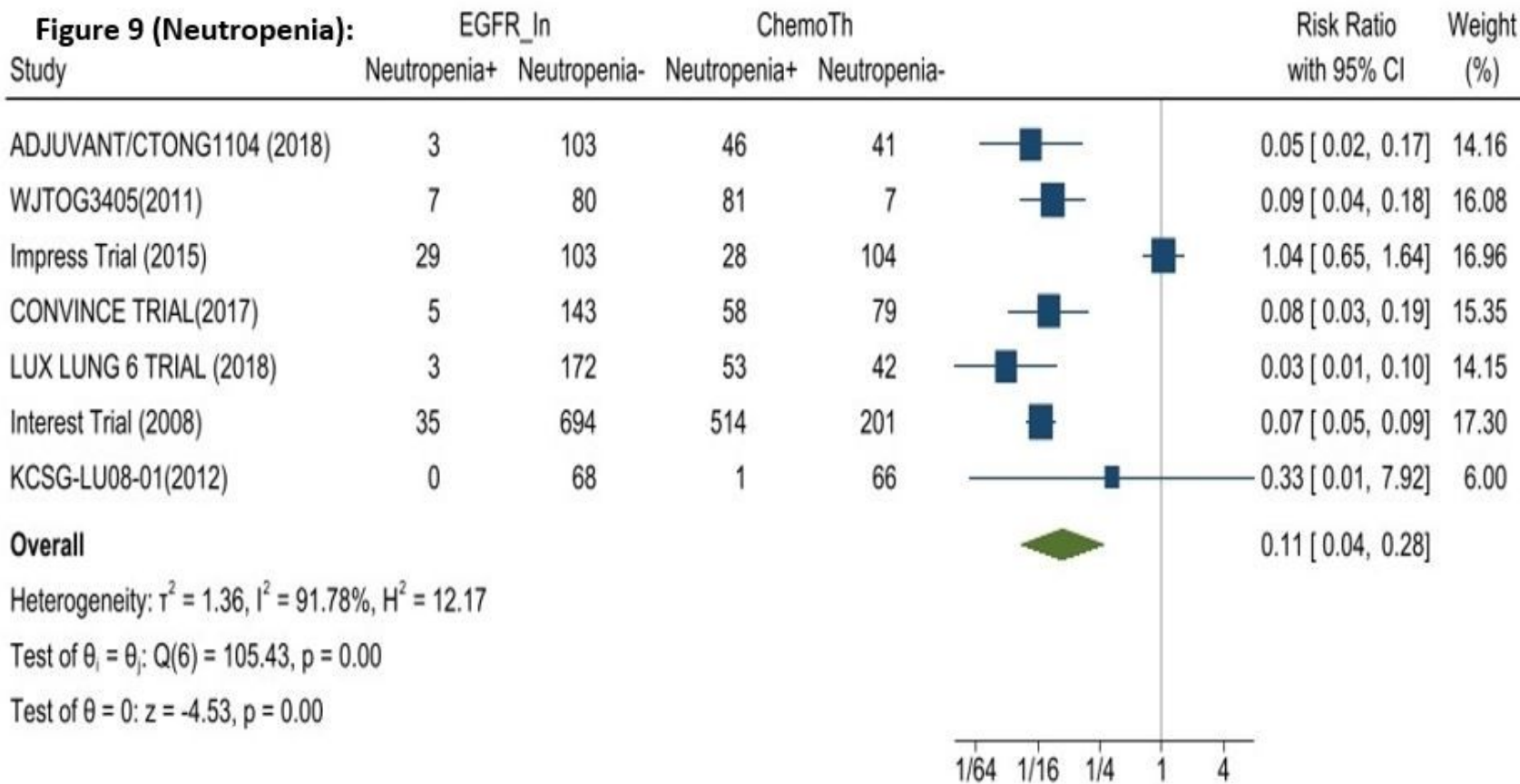

Random-effects REML model

\section{Figure 9}

The risk ratio above 1 indicates higher neutropenia event rates in the EGFR inhibitor group compared to the Chemotherapy group.

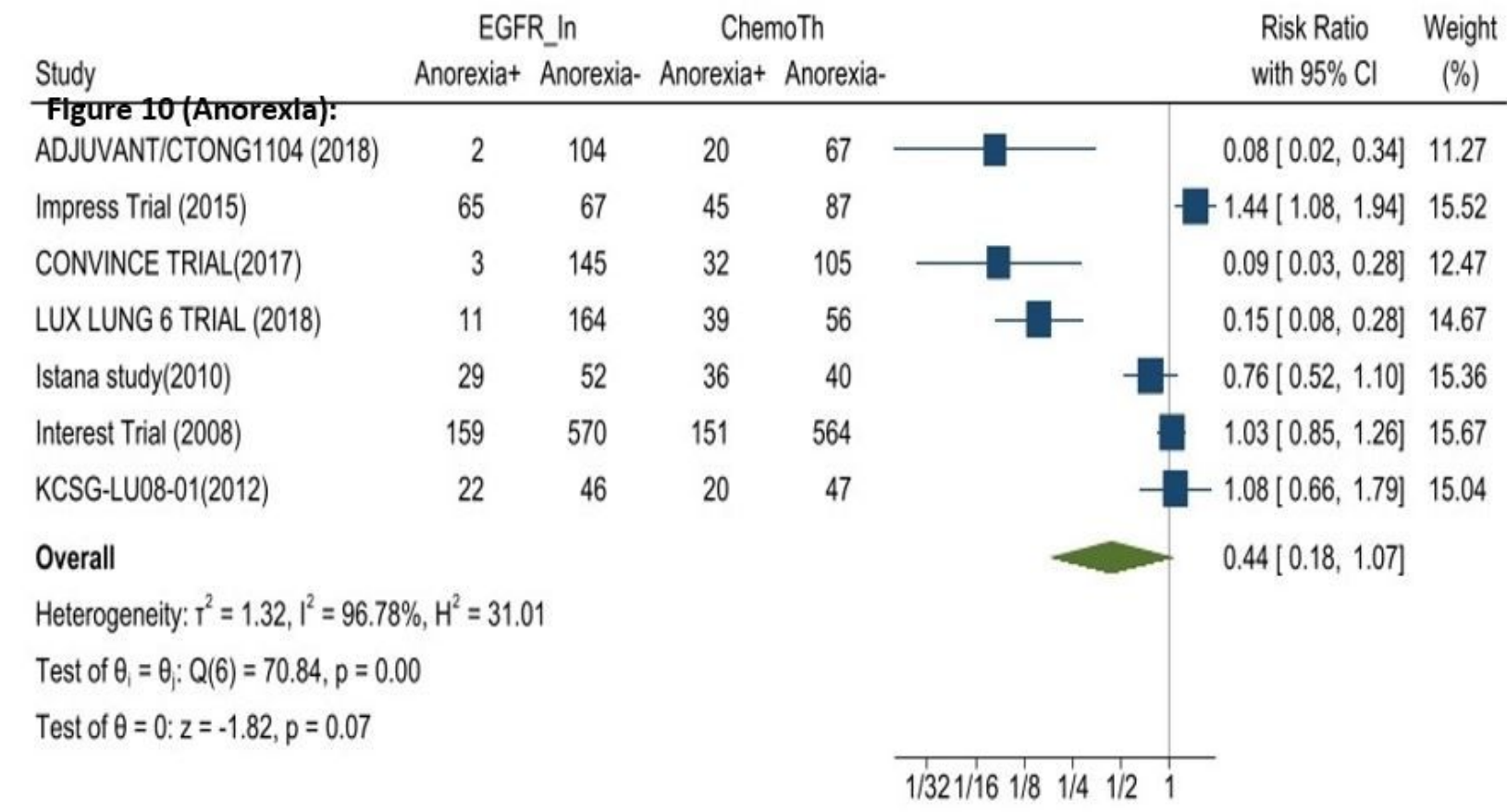

Random-effects REML model

Figure 10

The risk ratio above 1 indicates higher anorexia event rates in the EGFR inhibitor group compared to the Chemotherapy group. 


\begin{tabular}{|c|c|c|c|c|c|c|c|}
\hline \multirow[b]{2}{*}{ Study } & \multicolumn{2}{|c|}{ EGFR_In } & \multicolumn{2}{|c|}{ ChemoTh } & & \multirow{2}{*}{$\begin{array}{l}\text { Risk Ratio } \\
\text { with } 95 \% \mathrm{Cl}\end{array}$} & \multirow{2}{*}{$\begin{array}{c}\text { Weight } \\
(\%)\end{array}$} \\
\hline & Anemiat & Anemia- & Anemia+ & Anemia- & & & \\
\hline 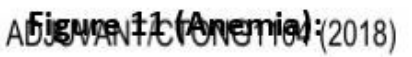 & 2 & 104 & 44 & 43 & - & $0.04[0.01,0.15]$ & 11.92 \\
\hline WJTOG3405(2011) & 33 & 54 & 79 & 9 & & $0.42[0.32,0.56]$ & 25.11 \\
\hline Impress Trial (2015) & 0 & 132 & 1 & 131 & & $-0.33[0.01,8.11]$ & 3.56 \\
\hline CONVINCE TRIAL(2017) & 4 & 144 & 17 & 120 & & $0.22[0.08,0.63]$ & 15.39 \\
\hline LUX LUNG 6 TRIAL (2018) & 9 & 166 & 26 & 69 & & $0.19[0.09,0.38]$ & 19.93 \\
\hline Interest Trial (2008) & 34 & 695 & 84 & 631 & & $0.40[0.27,0.58]$ & 24.09 \\
\hline Overall & & & & & & $0.24[0.12,0.45]$ & \\
\hline \multicolumn{8}{|c|}{ Heterogeneity: $\mathrm{T}^{2}=0.41, \mathrm{I}^{2}=81.41 \%, \mathrm{H}^{2}=5.38$} \\
\hline \multicolumn{8}{|l|}{ Test of $\theta_{1}=\theta_{j}: Q(5)=15.79, p=0.01$} \\
\hline \multicolumn{8}{|l|}{ Test of $\theta=0: z=-4.35, p=0.00$} \\
\hline & & & & & $1 / 64$ & 8 & \\
\hline
\end{tabular}

Random-effects REML model

Figure 11

The risk ratio above 1 indicates higher anemia event rates in the EGFR inhibitor group compared to the Chemotherapy group.

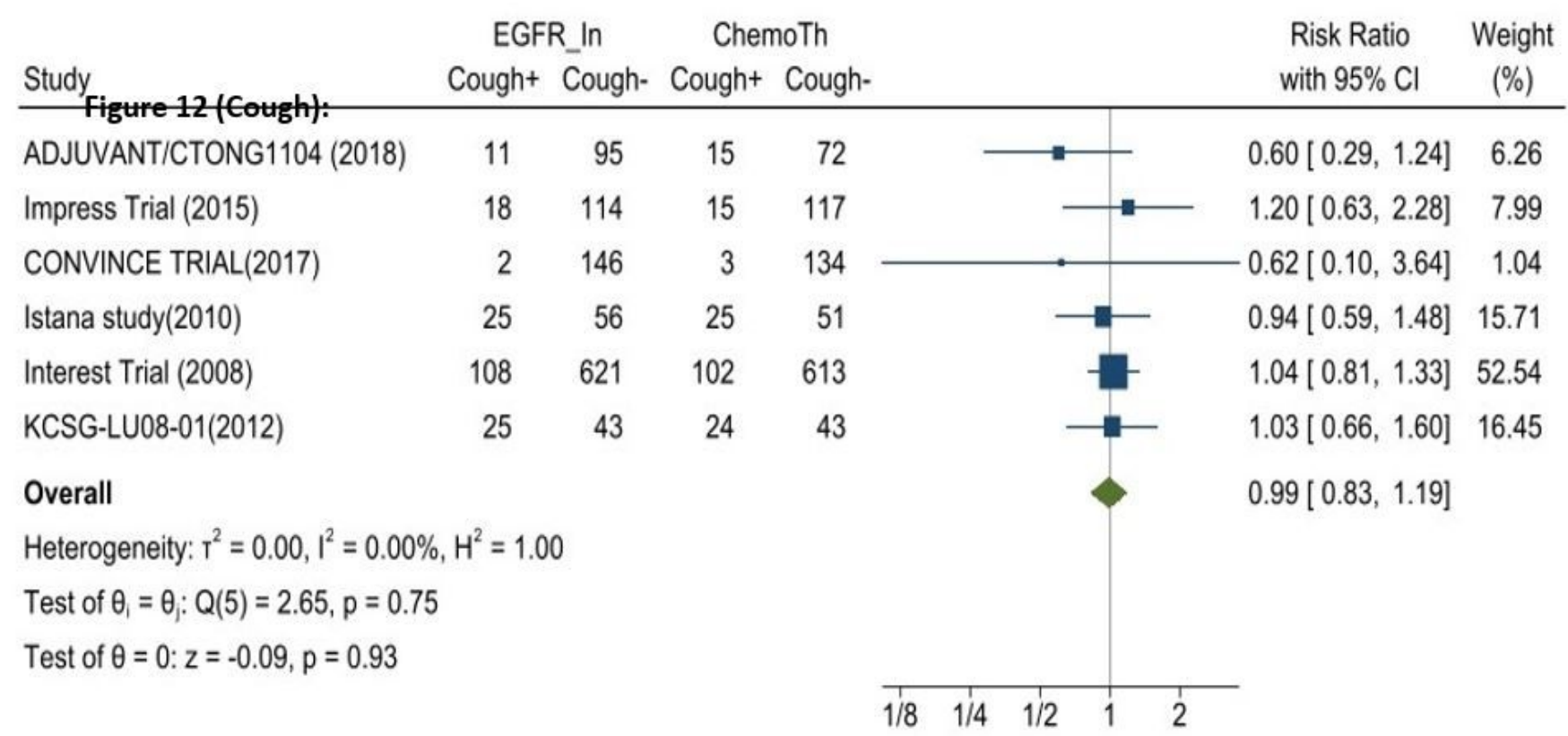

Random-effects REML model

Figure 12

The risk ratio above 1 indicates higher cough event rates in the EGFR inhibitor group compared to the Chemotherapy group. 


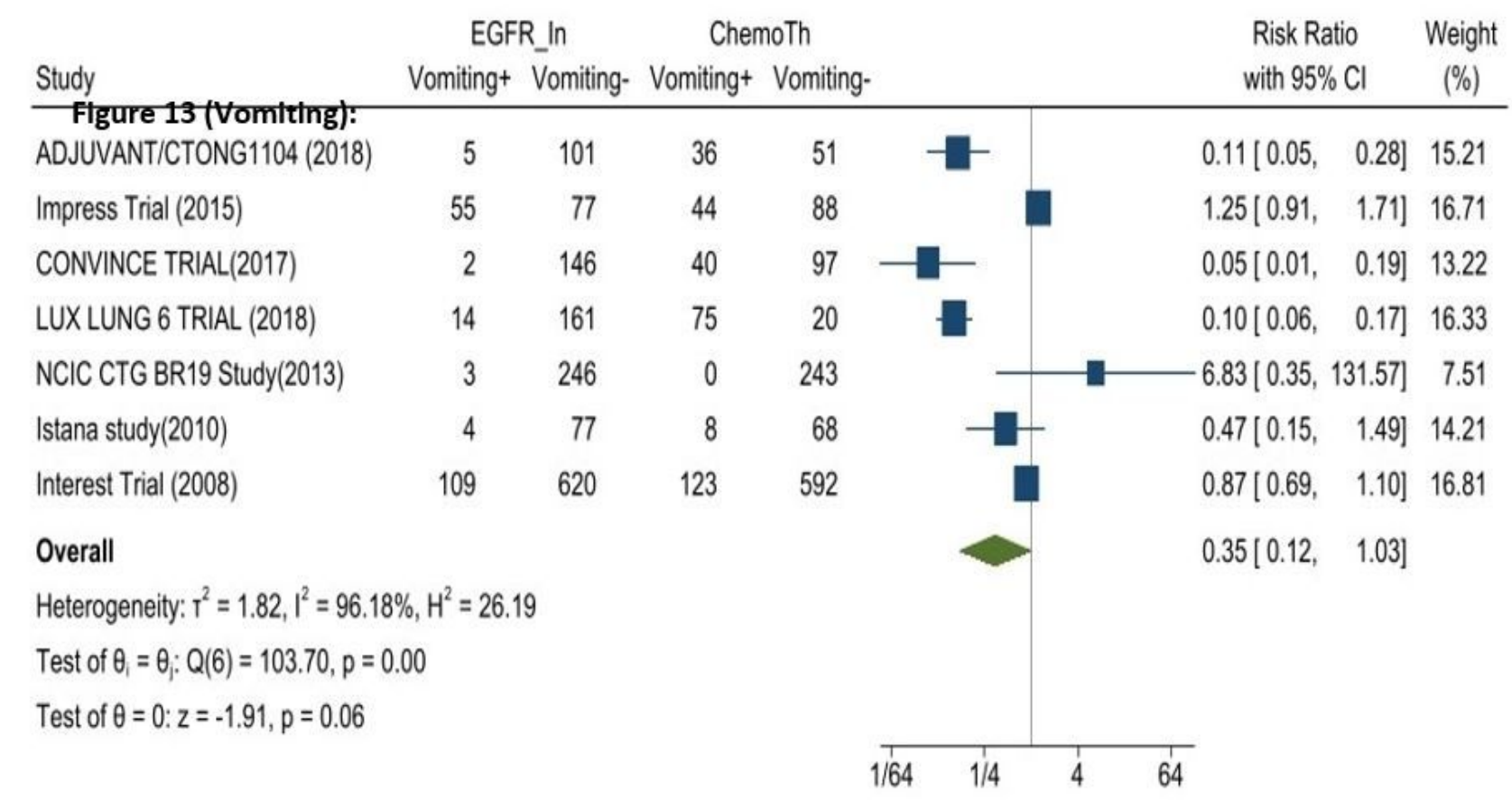

Random-effects REML model

Figure 13

The risk ratio above 1 indicates higher vomiting event rates in the EGFR inhibitor group compared to the Chemotherapy group.

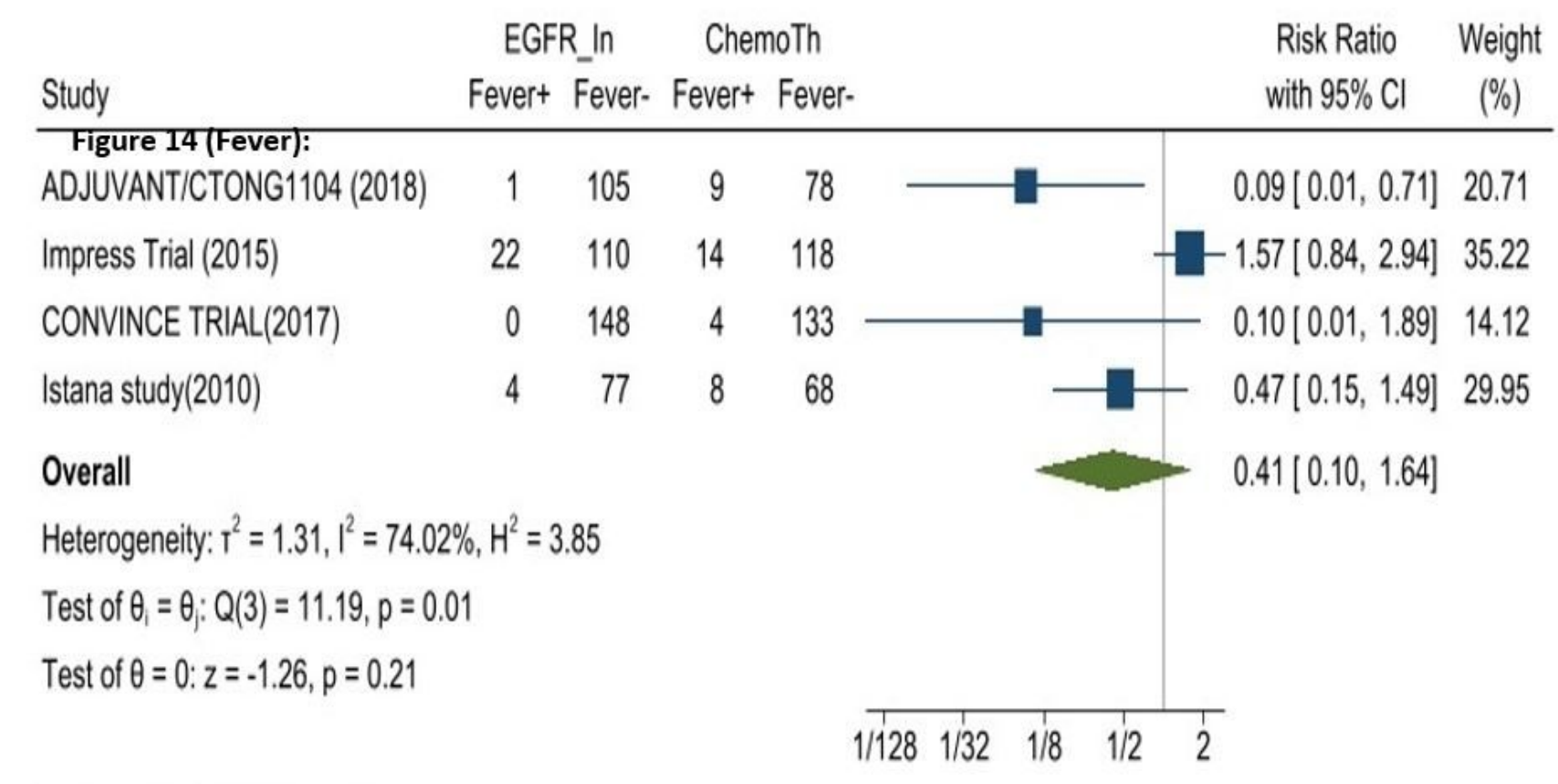

Random-effects REML model

Figure 14

The risk ratio above 1 indicates higher fever event rates in the EGFR inhibitor group compared to the Chemotherapy group. 